\title{
Geomorphological changes caused by Tsunami 2004 in the coastal environment of Weligama Bay in Southern Sri Lanka
}

\author{
S. Wijeratne* \\ Department of Geography, Faculty of Humanities and Social Sciences, University of Ruhuna, Matara, Sri Lanka.
}

\begin{abstract}
The coastal area of Weligama Bay was severely affected by the tsunami disaster on $26^{\text {th }}$ of December 2004 . It caused 396 deaths locally in addition to the destruction of valuable properties. Also most of the geomorphological features have been altered severely. The objective of this study was to examine how the tsunami waves have impacted on geomorphological features in Weligama Bay.
\end{abstract}

Changes in geomorphological features were identified through the analysis of satellite images before 2004 and after 2005. ArcView GIS software was used for hazardous mapping and damage analysis of the area. The pre and post-tsunami map overlay technique of ArcView software was used to determine the changes of geomorphological features in the area concerned.

The tsunami waves altered the coastal features by shrinking and spreading estuaries, eroding the coast and blocking the estuary. Such changes can be observed in the estuaries of Polwatta Ganga, Pemuyana and Rassamuna headlands, and Weligama Bay beach. North of the Polwatta Ganga estuary was broadened by about $5 \mathrm{~m}$ and the breath of sand spit of the estuary was increased in about $2 \mathrm{~m}$. The tsunami waves attacked the Pemuyana headland in the south of the bay causing serious damages to Weligama town area and the base of the headland was eroded by about $1 \mathrm{~m}$. The Kapparatota natural harbor which was located in the northern part of the bay of Weligama was altered as a bay beach by sand deposition.

Keywords: Tsunami, geomorphology, estuary, headland, sandspit.

\section{INTRODUCTION}

The coastal area of Weligama Bay is an attractive landscape owing to its varieties of landforms and ecosystems such as beaches, sandspits, estuaries, sea cliffs, headlands, mangroves, marshlands and corals (Terney \& Cumaranatunga, 2005). Apart from the aesthetic value, the area was benefitted by the establishment of specific socio economic activities. With the influence of these geomorphological features, many economic activities such as fisheries, tourism and coir processing are located in this area. Landforms and ecosystems helped to control the natural disasters to some extent, i.e. floods, storm waves. However, after the 2004 tsunami disaster, these geomorphological features in the area were altered leading to an imbalance of the coastal systems (Jayathissa et al., 2005).

According to the records of Coast Conservation Department, 3776 coastal habitats were in Matara and Galle districts in 1997 (CCD, 1990). Most of the resources were completely or partially affected by the tsunami waves which penetrated up to $1 \mathrm{~km}$ inland at certain places. It destroyed vegetation, changed landforms, created vast amounts of debris, released pollutants and contaminated soil and fresh water supplies. The occurence of tsunami has created many more environmental problems, such as, coastal pollution, coastal erosion and, degradation of landforms and coastal habitats (Silva, 2005).

Although studies have paid a great deal of attention on examining the human and socio-economic impacts of tsunami, researchers have not satisfactorily addressed the problems concerning the entire environment of the coastal area (Alwis, 2006). A few studies carried out so far have not paid adequate attention to these environmental aspects. As such, this study was conducted to determine the impact of tsunami on geomorphological features of Weligama Bay coastal environment.

\section{OBJECTIVES OF THE STUDY}

The main objective of this study was to examine, how the tsunami waves affected the coastal geomorphological environment of Weligama Bay area. 
In addition to the above major objective, this study is concerned with the following aspects,

(a) Identification of geomorphological features within the study area.

(b) Determination of tsunami wave process that caused the geomorphological changes.

(c) Analysis of coastal geomorphological changes on Weligama Bay beach.

\section{METHODOLOGY}

\section{Study area}

The study area was the coastal area of Weligama Bay stretching from Pemuyana headland to Rassamuna headland. This area represents the Weligama Divisional Secretariat and it is one of the worst damaged areas in the Matara District. Among the 29 Grama Niladari Divisions within this Divisional Secretariat, 22 were affected by the tsunami.

This is a densely populated area with a high concentration of many socio-economic activities. As a result of the tsunami, in this area, 396 people were killed and 2,466 families were displaced. 543 houses were completely damaged and most of the socio-economic activities of the area were ruined (Department of Census and Statistics, 2005). In addition, tsunami caused considerable changes in coastal landforms and ecosystems of the Weligama coast. Hence, Weligama coastal zone is selected as the study area covering these specific aspects.

The study area stretching from Pemuyana headland to Rassamuna headland, is demarcated by mean sea level in the west and tsunami affected boundary line (TABL) in the east (See Figure 1).

\section{Data collection}

Required data for this study were collected from available primary and secondary sources. Secondary data was collected from Weligama District Secretariat office, the Disaster Management Center and the Department of Census and Statistics, Sri Lanka. In order to make the study successful, several methods such as, tsunami mapping, questionnaire survey, target group discussion and field observations were used for relevant data collection.

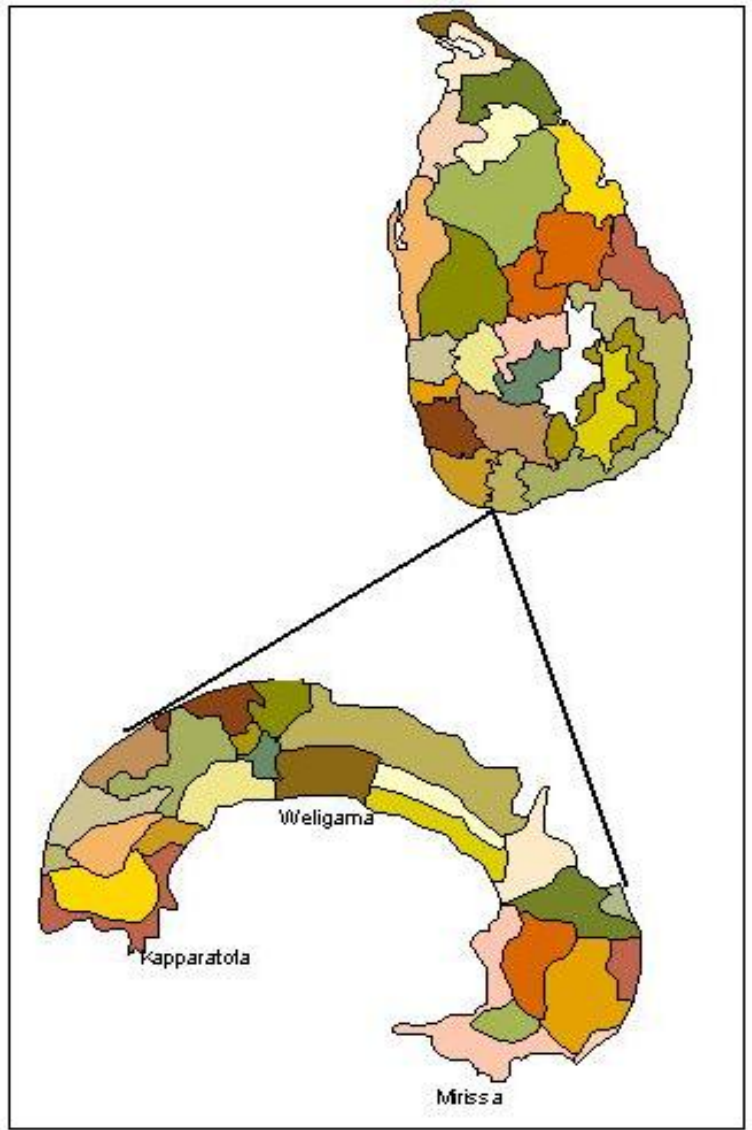

Figure 1: Location of the study area (from Mirissa to Kapparatota)

Source: Department of Census and Statistics, Sri Lanka 
The magnitude of the affected geomorphologic features and ecosystems were identified through the analysis of satellite images before 2004 and after tsunami, in 2005. ArcView GIS software was used for hazardous mapping and damage analysis in the area. Pre and after tsunami maps overlay technique of the ArcView software were used to determine the changes and damages of geomorphological features. Using these data, a tentative geomorphological map was constructed to demarcate the damages and changes of geomorphological units and this was verified through field work.

\section{GEOMORPHOLOGICAL CHANGES OF WELIGAMA COASTAL ENVIRONMENT}

Weligama Bay which is situated in southern Sri Lanka, is a geomorphologically and ecologically specific area.
This area consists of coastal landforms originated through various kinds of processes. There are bay beaches and allied features, bay and headlands, estuaries, beach rocks, alluvial plains, fluvio-marine plains, denudational hills and planation surfaces (See Figure 2). These originate due to the influence of marine, fluvial, fluvio-marine and denudational processes (Wijeratne, 2009).

Sea is the major causative factor in landform formation in the study area. It consists of a number of marine agents such as waves, currents and tides. In addition, shortterm and long-term sea level changes have affected the formation of landforms. Sea beaches, bays, islets, sand spits, sea cliffs, headlands can be observed within the area originated from marine process (Katupotha, 1998).

The fluvial process is the dominant process in creating landforms next to marine process. Polwatta River is the

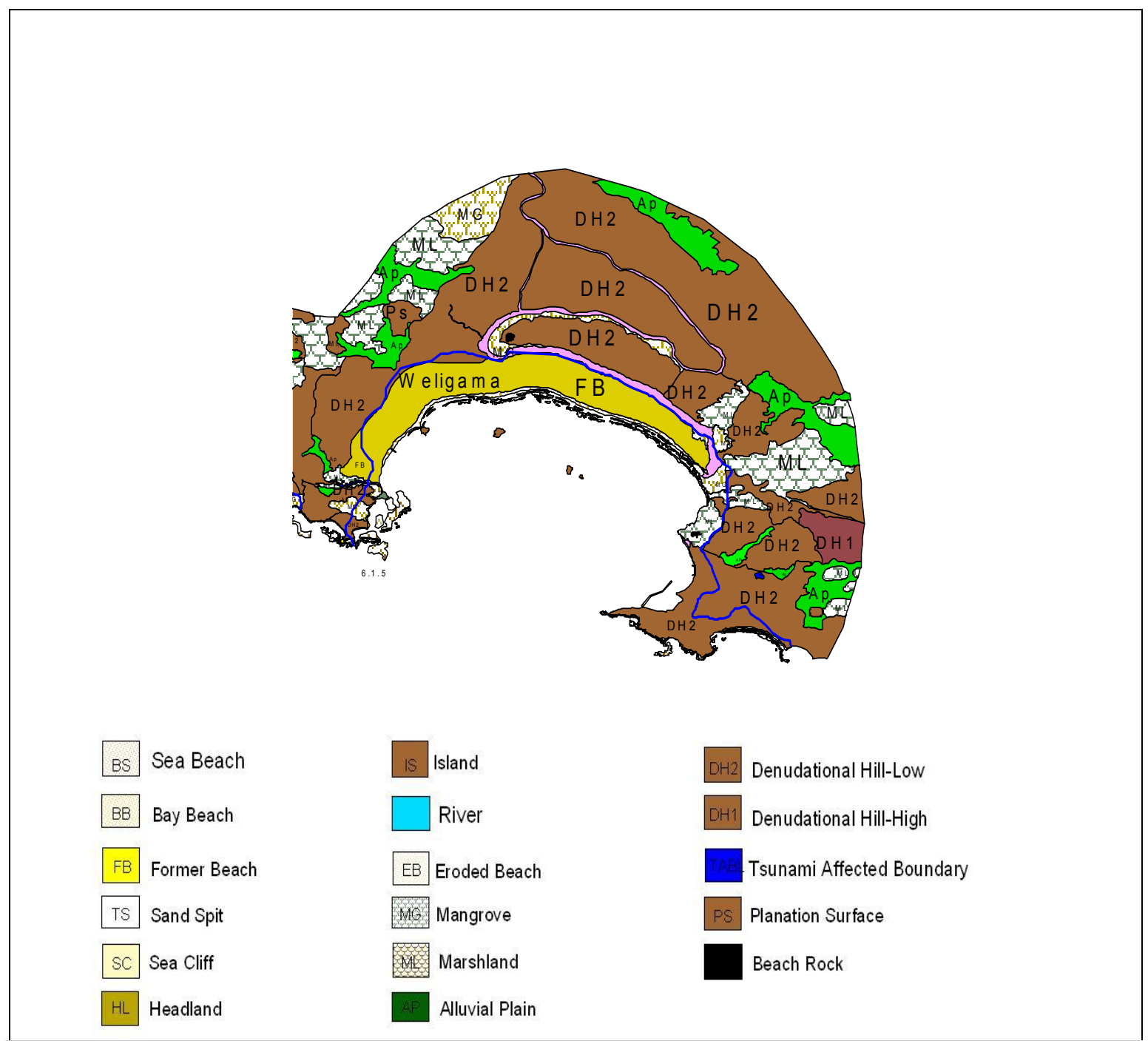

Figure 2: Geomorphologic map of Weligama Bay area

Source: This map was compiled based on Ikonos satellite images taken by Urban Development Authority, 2005. 
main source of formation of landforms and bringing sediment material to the coast. The amount of material brought through the Polwatta Ganga is deposited to form the landforms. As a result of these depositions, alluvial plains, spits and flood plains are originated.

Some landforms have been formed as a result of a mixture of marine and fluvial processes. In combination they form a fluvio-marine process. Lagoons are the major fluvio-marine land forms.

Generally, rocks are weathered by chemical, physical and organic actions under the influence of the climate, relief and morphology. Weathered material are transported by water, wind and waves and ultimately deposited in lowlands. They have caused erosion and denudation of the surface topographic features (Bird, 1976; Swan, 1983). Denudational hills, planation surfaces and rock outcrops are the broadly distributed denudational landforms in this area.

Similar to natural processes, human activities have also contributed to changes in landforms in the coastal area. The changes due to engineering constructions are prominent among human activities. Revetments and groynes are some examples of man-made landforms.

Although these landforms have contributed to preserve the coastal environment, most of them were completely or partially damaged even before the tsunami waves affected them. Marine landforms were highly affected by the tsunami waves. Bay beach, estuary, sand spits, beach rocks, headlands, sea cliffs and coastal structures are the specific coastal landforms which were heavily damaged and changed by tsunami. They could be identified by the interpretation of pre and post tsunami satellite images using Geographical Information System (GIS) and also they were compiled through geomorphologic maps (see Figure 02).

The tsunami waves caused the changes in coastal features by shrinking and spreading of estuaries, eroding the coast and blocking the estuaries. Such changes can be observed in the estuaries of Polwatta ganga, Pemuyana and Rassamuna headlands and Weligama Bay beach. The changes in these areas were studied under the three sections as mentioned below.

a. Changes in headlands in Weligama Bay

b. Changes in Polwatta Ganga estuaries and sand spit

c. Changes in the coastline of the Weligama Bay

\section{Changes in headlands in Weligama Bay}

The headlands, which are located on both sides of the Weligama Bay, are the main geomorphological features that contributed to the formation of the Weligama Bay beach. The concave area which is stretched between Pemuyana headland in the south and Rassamuna headland in the north is identified as Weligama Bay. The height of these two headlands is about $15-30 \mathrm{~m}$ and they are the main morphological features which change the process of Weligama Bay beach. The sea waves which flow into the bay strike against these two headlands and it may cause to reduce wave velocity and coastal erosion. Also, it affected the formation of a broad beach in the area. The location of these headlands were altered due to the tsunami process as well as the normal sea wave process. Although Weligama area was severely damaged by tsunami, the damages would have been more severe had these two headlands not existed.

The tsunami wave which attacked Pemuyana headland situated in the south of Weligama Bay, has refracted towards the northwest and north of the bay causing serious damages to the Weligama town. It is also the main reason for the highest damages in the Weligama Bay beach area. But, there was no major damage on Pemuyana headland because it is a high mountainous area with $30 \mathrm{~m}$ in height and it is made of granite rocks. But, the base of the headland was eroded about one meter above the sea level and the headland was narrowed because of the erosion of $300 \mathrm{~m}$ of the headlands.

Rassamuna headland in the north of Weligama Bay was eroded more than the Pemuyana headland. The basement of the sea cliff on Galbokka pocket beach and Gurukanda have been eroded by $15 \mathrm{~m}$ from the sea level because the tsunami wave that arrived from westward and the waves from the south of the bay attacked this headland. The waves which struck against the headland turned into the Galbokka marshland, and it was expanded because of stagnant water.

\section{Changes in the Polwatta Ganga estuary and sandspit}

Polwatta Ganga is the major river flowing across the Weligama Bay. This river flowing with meandering towards the north of the coastline approaches the sea, close to the Pemuyana headland. Estuary, sandspit, sea cliff, mangrove, former beach and beach rocks are the landforms distributed around the Polwatta Ganga estuary and most of them were impacted by the tsunami. Because of the tsunami waves, the estuary was affected only marginally. To the north of the estuary, the breadth was increased by about $5 \mathrm{~m}$ and also, the breadth of sand spit of the estuary was increased by about $2 \mathrm{~m}$. Around 5000-6000 years ago, the Holocene sea level was accelerated by $1 \mathrm{~m}$ and it created river meanders as an upward movement of the river (Weerakkody, 1990). Not only the long-term sea level rise, but also a sudden sea level rise caused by tsunami, storm waves produced 
coastal changes. Thus, tsunami waves in 2004 caused significant changes to the Polwatta Ganga estuary.

Tsunami waves penetrated $500 \mathrm{~m}$ inland and river meandering obstructed further flow of water towards the upper areas. Because of these disturbances, river banks were sedimented with marine deposits and it damaged the mangroves about $5 \mathrm{~m}$ along both the river banks.

The sand spit of the estuary was developed by tsunami and sand accumulated on flood plain of the both sides of the river banks by about 2 feet in thickness. Sand spit was spread by $2 \mathrm{~m}$ and north of the estuary was broadened by $2 \mathrm{~m}$ and deepened by $1 \mathrm{~m}$. By this time, landscape of the river outfall has been changed by the re-development of a sand barrier. But, basement of the sea cliff has eroded up to $15 \mathrm{~m}$ in height, as the tsunami waves attacked on the cliff base. However, the damage to the estuary was

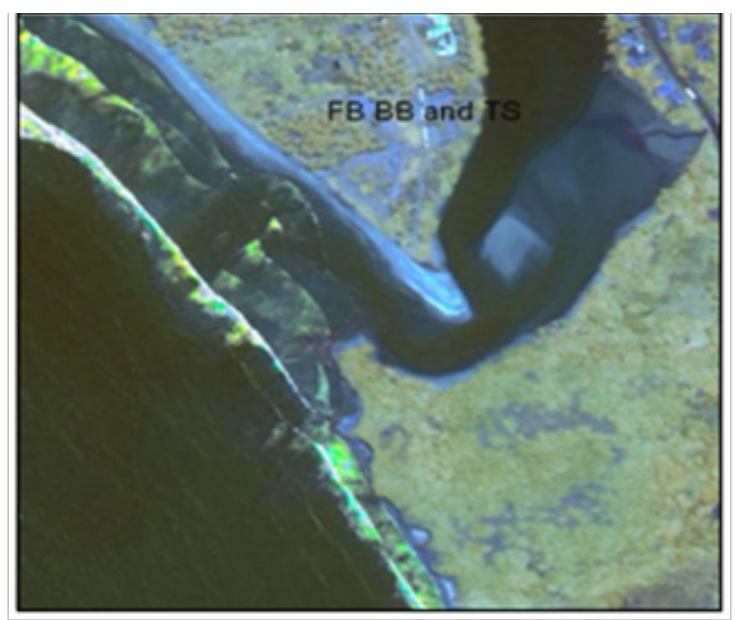

Figure 3: Polwatta Ganga estuary-before tsunami

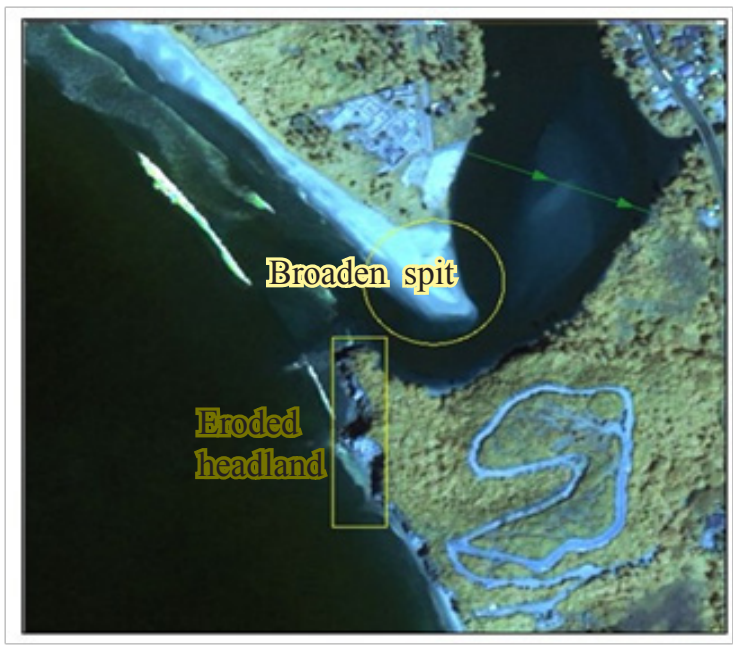

Figure 4: Changes of Polwatta Ganga estuary-after tsunami comparatively lower than Weligama Bay area as a result of refracted tsunami waves from the Pemuyana headland after tsunami.

\section{Changes in the coastline of Weligama Bay}

Weligama coastline stretched from Pemuyana headland to Rassamuna headland is the bay beach area. This coastline with concave shape is a broad flat terrain. The depth of the coastline sea floor is less than $5 \mathrm{~m}$ and the height of the coastline is not more than $1 \mathrm{~m}$. This area with flat terrain was severely affected by the tsunami and eroded the coastline by $2 \mathrm{~m}$ towards the land area, and also the coastline was polluted with accumulation of debris. Buildings and properties were also much damaged.

The bay was geomorphologically changed because of sand deposition on the northern part of it. Tsunami waves refracted towards the north-west of the bay, and the northern part of the bay beach was formed further with beach materials transported by the tsunami waves from south to north direction. It has resulted in a broadened beach of about $15 \mathrm{~m}$ in width and former offshore coast had changed into a sandy beach now. As a result of this, at present it is clear, that the Kapparatota natural harbor has changed into a bay beach area (See Figure 5 and 6).

\section{CONCLUSIONS}

The coastal landscape of Weligama Bay has a variety of coastal landforms, originated from processes of marine, fluvial, fluvio-marine, winds and denudation. But almost $75 \%$ of geomorphologic units has been impacted by the

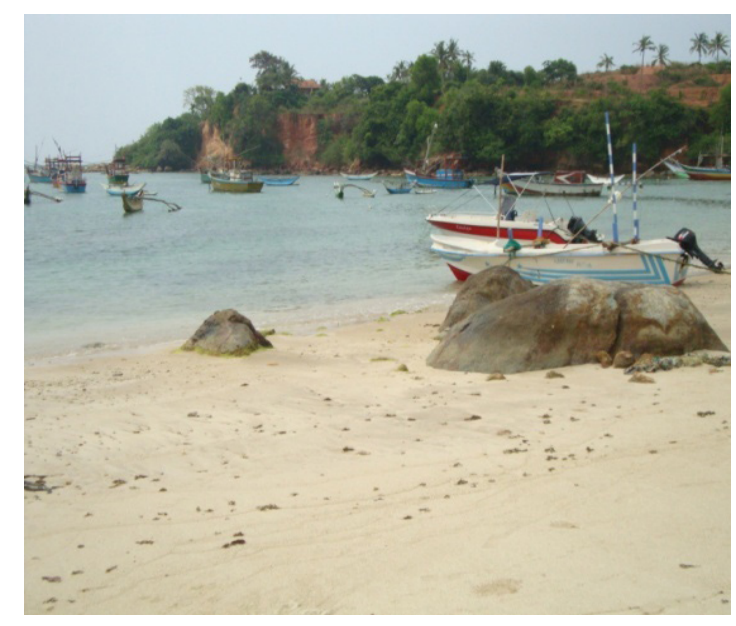

Figure 5: Prograded beach after tsunami by accumulation of sand-Kapparatota 


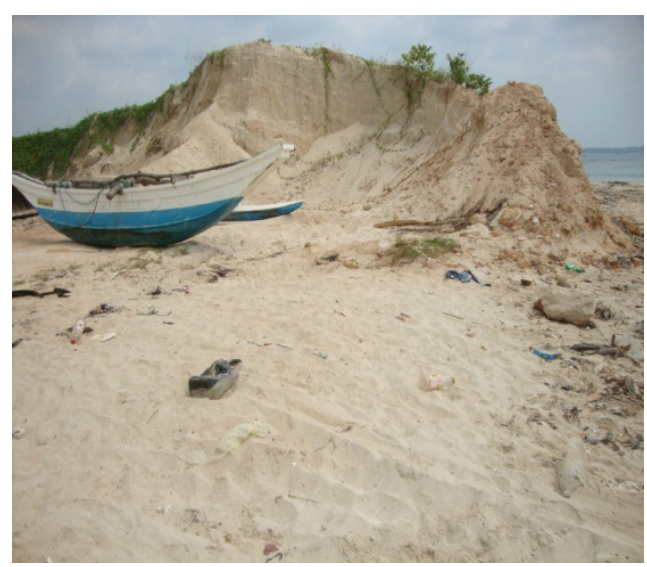

Figure 6: Collected sand deposits- Kapparatota harbor

the 2004 tsunami. The bay beach and its allied features such as, headlands, sand spits, sea cliff, marshlands and estuaries were the mostly damaged and changed landforms of the area.

Apart from the damages, several tsunami-induced changes of geomorphologic features could be identified. These changes are broadening, narrowing and blocking of river outfalls, broadening and sedimentation of marshlands and sand spits. Such changes can be observed in the estuaries of Polwatta Ganga, Pemuyana and Rassamuna headlands and Weligama Bay beach.

North of the Polwatta Ganga estuary was broadened by about $5 \mathrm{~m}$ and the breath of sand spit of the estuary was increased by about two meters. The tsunami waves attacked the Pemuyana headland in the south of the bay causing serious damages to the Weligama town area and the base of the headlands was eroded by about $1 \mathrm{~m}$ and they were narrowed because of the erosion of nearly $300 \mathrm{~m}$ of the headlands. Rassamuna headland in the north of Weligama Bay was eroded more than Pemuyana headland.

The bay was geomorphologically transformed because of sand deposition on the northern part. As a result of this, the Kapparatota natural harbor which was located in the northern part of the bay has been turned into a bay-beach by sand deposition. Accordingly, among the changes of geomorphologic features that could be identified, baybeach, river outfall, sand spits and marshlands are the most severly impacted coastal features.

\section{REFERENCES}

Alwis, A. (2006) Impact assessment of $100 \mathrm{~m}$ and $200 \mathrm{~m}$ coast conservation buffer zone declaration on socio economic conditions of the coastal communities and its effect on the coastal environment, Colombo: Coast Conservation Department, pp: 43-51.

Bird, E. C. F. (1976) Coasts, An introduction to systematic Geomorpholgy, Vol. 04, $2^{\text {nd }}$ edition, National Library of Australia.

Coast Conservation Department (1990) Coastal zone management plan, Colombo, pp: 33-49.

Department of Census and Statistics (2005) Preliminary statistics of the census of population and buildings of the census blocks affected by the Tsunami-2004, pp: 1-29.

Jayathissa, L. P., Satyanarayana, B., Kodikara, K. A. S. and Dissanayake, N. P. (2005) Did maritime vegetation protect lives and property in Sri Lankan coasts against Tsunami, A report on impact of the Tsunami and post Tsunami recovery in the Southern region of Sri Lanka, Matara, Sri Lanka: University of Ruhuna, pp: 21-27.

Katupotha, J. (1998) Evolution of coastal landforms in the Western part of Sri Lanka, Geographical Sciences, 43(01), pp: 18-36.

Silva, M. P. (2005) Tsunami impact on coastal ecosystems with special reference to vegetation in Hambantota District, New Delhi: Mosaic Books, pp: 155-163.

Swan, B. (1983) An introduction to the coastal geomorphology of Sri Lanka, National Museums of Sri Lanka, pp: 56-99.

Terney, P. K. \& Cumaranathunga, P. R. T. (2005) Impacts of the tsunami on coral reef ecosystems along the Southern coast of Sri Lanka, A report on impact of the Tsunami and Post Tsunami Recovery in the Southern region of Sri Lanka, Matara, Sri Lanka: University of Ruhuna.

Weerakkody, U. (1990) Geomorphologic Evolution of the South-west coast of Sri Lanka, National Museums of Sri Lanka, pp: 115-133.

Wijeratne, S. (2009) Analysis of spatial distribution of coastal landforms in the Southwest coastal area of Sri Lanka, Journal of the Faculty of Humanities and Social Sciences, 5, Matara, Sri Lanka: University of Ruhuna, pp: 305-327. 